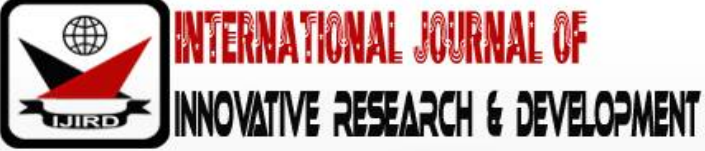

ISSN 2278 - 0211 (Online)

\section{Impact of Soill Erosion Predictor Variables on Soil Loss Rates in Biu Area, Borno State, Nigeria}

\author{
Ibrahim Madu \\ Lecturer, Department of Agricultural Education, College of Education Waka- Biu, Borno State, Nigeria \\ Abubakar M. Kundiri \\ Lecturer, Department of Soil Science, University of Maiduguri, Borno State, Nigeria
}

\begin{abstract}
:
A study on impact of soil erosion predictor variables was carried out at six locations: Kigir, Piku, Daura, Mirnga, Garwashina, and Tum. The aim of the study was to analyse the effects of erosion predictor variables on soil loss rates in Biu Area. There are fourteen (14) soil erosion predictor variables used in the study: soil clay content, erodibility, Bulk density, Organic matter, Soil shear strength, Site slope rating, Rainfall and runoff factor, Cover and management factor, Support practice factor, Temperature of the study area, Soil sodium, Plastic limits, Soil calcium, and Soil infiltration rates with their values as 17.00 $32.00 \%, 0.25-0.35 \mathrm{~K}, 1.25-1.38 \mathrm{~g} / \mathrm{cm}^{3}, 2.34-6.57 \%, 0.012-0.081 \mathrm{KPa}, 20.00-25.00 \%, 289.12-396.87 \mathrm{~mm}, 0.04-0.40$ $\%, 0.2-1.0,24-32{ }^{\circ} \mathrm{C}, 0.39-1.74 \mathrm{Cmol}(+) / \mathrm{kg}, 5.78-18.53 \%, 3.80-16.00 \mathrm{Cmol}(+) / \mathrm{kg}$, and $1.66-14.85 \mathrm{mmh}^{-1}$, respectively. The mean values of the 14 selected erosion predictor variables for the different sites were significant $(\mathrm{p}<0.05)$ different. The values were significantly higher at Daura, Piku, and Kigir compared to Mirnga, Garwashina and Tum sites. The site did not differ significantly in terms of bulk density, organic matter content, site slope rating, soil shear strength, cover and management factor, support practice factor and soil sodium.
\end{abstract}

Keywords: Rainfall and runoff factor, soil shear strength, infiltration rates, organic matter content, site slope rating, erodibility, cover and management factor

\section{Introduction}

Soil erosion is widely predicted as a function of six important factors, including rainfall erosivity, soil erodibility, slope length, slope steepness, cover management, and support practice [1]. Runoff and erosion estimates are made using various models ranging from purely empirical to mechanistic. The complexity of such models depends on its mathematical formulation and the set of input variables needed to apply them. Complexity of process description in runoff erosion models varies from empirical equation like in soil conservation curve numbers method and RUSLE [2], to mechanistic physically based models such as WEPP [3] and RHEM [4]. The product of slope length L and steepness S, called topographical factor LS, is the rate of soil loss from the field slope length and gradient to soil loss from a standard plot under otherwise identified condition [5]. The $\mathrm{C}$ factor is the rate of soil loss from an area with specified cover. This factor reflects the effect of ground and vegetation cover on the reduction of soil loss by reducing rainfall and runoff. In the RUSLE, the $\mathrm{C}$ factor is a product of five subs - factors, including prior land use, canopy cover, surface cover, surface roughness, and soil moisture [5]. The $\mathrm{P}$ factor is the rate of soil loss with a support practice such as contorting, strip cropping, terracing etc. Here it was assumed that $P=1$, because of no support practice. Generally, soil loss is most sensitive to the LS factor, and $\mathrm{C}$ factor $[6,7,8,9]$. Erodibility $(\mathrm{K})$ defines the resistance of the soil both detachment and transport. Although a soil resistance to erosion depends in part on topographic position, slope steepness and the amount of disturbance, such as during tillage, the properties of the soil are the most important determinant. Erodibility varies with soil texture, aggregate stability, shear strength, infiltration capacity, organic and chemical content, soil structure, surface sealing and antecedent soil water content $[10,11]$.

Biu lies on the Biu plateau at an average elevation of $768 \mathrm{~m}$ above sea level. The region is semi-Arid. The Local Government Area is mostly located in the Northern Guinea Savannah agro - ecological zone, with small portion in the North east. The Kimba area lies in the drier Sudan Savannah Zone [12]. The aim of this paper is to assess the impact of soil erosion predictor variables on soil loss rates in Biu Area. Soil loss caused by erosion on farm lands in Biu and Sade town in both Borno and Bauchi States of North - eastern Nigeria ranged from 1000 and 3100 tones ha-1 $\mathrm{yr}^{-1}$ [13, 14]. Despite the impact of soil erosion predictor variables on soil loss rates in Biu Area, there is still lack of information on the scale and magnitude of the scourge in the study area, and therefore the need to design appropriate management techniques in order to water erosion problems on farmlands. The present study is expected to provide necessary information on the extents, measures, and direction for prospective users including governmental agencies and a number of policy makers on their effort to manage erosion problems in the area. 


\section{The Study Area}

The study was conducted in Biu, North Eastern Nigeria, in Borno State in 2016. There are six sites for the study

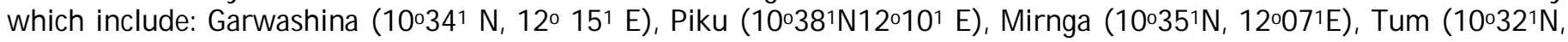
$\left.12^{\circ} 17^{1} \mathrm{E}\right)$, Kigir $\left(10^{\circ} 30^{1} \mathrm{~N}, 12^{\circ} 13^{1} \mathrm{E}\right)$, and Daura $\left(10^{\circ} 34^{1} \mathrm{~N}, 12^{\circ} 14^{1} \mathrm{E}\right)$. The sites were selected based on the differences in land use, topography, vegetation cover and soil types. Biu town has tropical climate, consisting of dry season from November to March followed by wet season from April to October. The rainfall varies with season. The average rainfall of the year is $917.19 \mathrm{~mm}$. The average daily temperatures are between 22 and $24{ }^{\circ} \mathrm{C}$, and during the harmatan the maximum temperatures are between 26 and $28{ }^{\circ} \mathrm{C}[15,16]$.

\section{Materials and Method}

\subsection{Field Study}

Soil sampling was conducted at six sites (Kigir, Piku, Daura, Mirnga, Garwashina and Tum). Large plot or watershed with the size of $100 \mathrm{~m}^{2}$ [17], was selected at random and three (3) soil samples collected at each site for laboratory analysis. Also, the water erosion predictor variables such as rainfall and runoff factor, site slope rating, cover and management factor, infiltration rate and soil shear strength were measured. Eighteen (18) composite soil samples were collected for one growing season, using bucket auger. Each soil sample was collected when moist in a well - labelled Polyethene bag. The samples were air - dried ground and sieved through a $2 \mathrm{~mm}$ sieve, then prepared and analysed for some physical and chemical parameters that relates to soil erosion. Soil infiltration rates were measured by double rings infiltrometers [18].

The erodibility index was computed in accordance with the corresponding erodibility factor units ( $\mathrm{K}$ - value) for tropical soils describe by [19]. Cover and management factor (C), was measured using [27] method. Support practice factor was also measured by [27] method. The rainfall data used was 10 year - 24 hours rainfall amount and was collected using a rain gauge devise for all rainfall events during the study periods. The amount of rainfall of rainfall received using rain gauge between $9.00 \mathrm{am}$ (the first day) and $9.00 \mathrm{am}$ (the next day) totalling 24 hours duration having 10 years return period. To determine the runoff factor $(\mathrm{R})[2,27]$ models were used. The models are as follows:

- $\mathrm{R}=\mathrm{P} \times 0.5[20]$

- $\quad \mathrm{E}(\mathrm{KE}>25)=9.28 \mathrm{P}-8838[21]$

- $\mathrm{EI}_{30}=0.276 \mathrm{P} \mathrm{x} \mathrm{I}_{30}[22]$

\subsection{Laboratory Study}

\subsubsection{Determination of Soil Physical Properties}

The determination of soil physical properties was conducted in the laboratory following standard procedures. The particle distribution was determined by the Bouyoucous hydrometer method [23]. The bulk density was determined by Cloud method [24, 28], while the water holding capacity was measured by gravimetric water content of a given quantity of soil fully saturated with water [23]. The Atterberg Limit comprised liquid and plastic limits. Both properties were determined. The soil liquid limit was determined using cone penetrometer method (BS 1377 part 2: 1990: 4:3), while the soil plastic limit was studied using a one cone point penetrometer method as described by [25]. The soil shear strength was measured by a torvane pocket penetrometer, and the impact penetrometer. The measurement was performed in the different sectors of the soil at each site. The permeability coefficient was determined in the laboratory using the rating head permeability test as outlined by [25].

\subsubsection{Determination of Soil Chemical Properties}

The soil PH was measured in a 1:2:5 soils: water suspension ratio using a glass electrode, PH meter (model 5) inserted into the suspension and left for one hour until equilibrium was reached for one hour with occasional string [24, 28]. The electrical conductivity (EC) was determined on a saturation paste using EC meter. The organic carbon (OC) content was determined using potassium dichromate wet - oxidation method by [26] method. The OC content was converted to organic matter (OM) by multiplying with a factor of 1.724. Total Nitrogen was determined by Khjeldahl method. While the available Phosphorus (P) by Bray 1, method [29]. The exchangeable Potassium (K) and Sodium (Na) was determined by Flame Photometry [30]. The exchangeable calcium ( $\mathrm{Ca}$ ) and Magnesium ( $\mathrm{Mg}$ ) was determined by titrimetric method, while the total exchangeable bases (TEB), and was computed as a summation of exchangeable bases.

\subsection{Soil Loss Models}

\subsubsection{Empirical Model (Conceptual Model)}

Soil loss estimation was performed using separate analysis of multiple linear regression of mass of soil loss against selected (14) predictor variables (Soil bulk density, Soil clay, Soil calcium (Ca) content, Support practice factor, Soil sodium (Na) content, Erodibility, Soil plastic limits, Site slope rating, Temperature of the study area, Infiltration rates, Rainfall and runoff factor (R), Soil organic matter, Cover and management factor, and Soil shear strength. The resultant coefficient of determination $\left(\mathrm{r}^{2}\right)$ of the predictor variables were used to show the relative impact on soil loss. The multiple linear regression equation is given as:

$Y=\alpha+\beta_{1} X_{1}+\beta_{2} X_{2}+\beta_{3} X_{3}+\beta_{4} X_{4}+\ldots \ldots \ldots \ldots+\beta_{14} X_{14}$

Where: $Y=$ estimate of soil loss 
$\alpha$ and $\beta=$ regression parameters

$\mathrm{X}=$ soil erosion predictor variable

\subsubsection{RUSLE 2, 2008 Model}

Version 2, of the revised Universal Soil Loss Equation (RUSLE 2), 2008 estimate soil loss from rill erosion caused by rainfall and its associated overland flow. It can be used on crop land, pasture land, landfills, military land, and other areas where mineral soil is exposed to raindrop impact and surface overland flow produced by rainfall intensity exceeding infiltration rate (That is Hortonian over land flow), [31]. The model is as follows:

$$
\mathrm{a}_{\mathrm{i}}=\mathrm{r}_{\mathrm{i}} \mathrm{k}_{\mathrm{i}} \mathrm{LSc}_{\mathrm{i}} \mathrm{p}_{\mathrm{i}}[31]
$$

Where: $\mathrm{a}_{\mathrm{i}}=$ Long - time average soil loss for ith day

$\mathrm{r}_{\mathrm{i}}=$ Erosivity factor

$\mathrm{k}_{\mathrm{i}}=$ Erodibility factor

$\mathrm{L}=$ Slope length factor

$\mathrm{S}=$ Slope steepness factor

$\mathrm{C}_{\mathrm{i}}=$ Cover and management factor

$\mathrm{Pi}=$ Support practice factor

\subsection{Data Analysis}

The data generated were subjected to Geometric Mean Error ratio (GMER) and Geometric Standard Deviation of Error Ratio (GSDER), using generalized linear model of Statistix 10, (2013). Statistically different means at ( $p<0.05)$ were separated using SE. The soil loss trends were validated both monthly and annually at locational bases.

\section{Results and Discursion}

\subsection{Soil Physical Properties, Annual Precipitation, Erosivity and Cover Condition of the Study Sites}

Table 1, shows soil texture of Piku and Tum sites, which are both loam and that of Kigir and Garwashina are clay loam, and Daura and Mirnga silt loam and sandy clay loam. Water holding capacities of all sites ranged from $20.70-31.50$ $\%$, respectively, thus showed significantly difference $(p<0.05)$. Result of the particle size distribution showed that clay, silt and loam ranged from 17.00 - 32.00, 21.60 - 53.90, and 23.90 - 53.90 \%, respectively. Soil particle distribution, water holding capacity and texture are factors influencing the perme abilities of clay soils, this observation concurs with that of [42]. Annual precipitation ranged from 697.56 - $827.66 \mathrm{~mm}$, which were recorded at Tum and Daura sites, respectively. Also, erosivity varies from $780-701 \mathrm{MJmmha}^{-1} \mathrm{~h}^{-1}$, respectively at the same stated sites. Intensity is the most important soil property which determines the amount of erosion in a specific location. Combination of high amount of rainfall with high intensity produces high erosion risk [11]. All the sites were cultivated with corn, guinea corn and groundnut.

\begin{tabular}{|c|c|c|c|c|c|}
\hline Site & Texture & Water Holding & Annual Precip & Erosivity $\left(\mathrm{EI}_{30}\right)$ & Cover Condition \\
\hline & & Capacity (\%) & $(\mathrm{mm})$ & $\left(\right.$ MJmmha $\left.^{-1} \mathbf{h}^{-1}\right)$ & (Cultivated) \\
\hline Kigir & $\mathrm{CL}$ & 30.90 & 784.90 & 726 & Corn \\
\hline Piku & $\mathrm{L}$ & 24.50 & 796.82 & 730 & Corn \& G/ corn \\
\hline Daura & SL & 20.70 & 827.66 & 780 & Groundnut \\
\hline Mirnga & SCL & 27.30 & 712.82 & 710 & Groundnut \\
\hline Garwas & $\mathrm{CL}$ & 31.50 & 752.81 & 715 & Corn \\
\hline Tum & $\mathrm{L}$ & 25.60 & 697.56 & 701 & Corn \\
\hline $\mathrm{SE}(+/-) 0.05$ & & 2.012 & & 11.44 & \\
\hline
\end{tabular}

Table 1: Physical Properties of Soil, Annual Precipitation, Erosivity and Cover Condition of the Study Sites

Key: CL = Clay Loam, L = Loam, SL = Silt Loam, SCL =Sandy Clay Loam Source: (Based on Field Study 2016)

\subsection{Chemical Properties of Soils of the Study Sites}

Table 2, shows the chemical properties of soils of the study sites. The $\mathrm{p} \mathrm{H}$ ranged from $7.28-7.96$. Soil reaction is higher at Piku and Kigir sites. The soil electrical conductivity ranged from $0.03-0.04 \mathrm{dSm}^{-1}$, which is relatively higher at Piku, Mirnga, Garwashina and Tum, respectively compared to other sites which had relatively low salt concentration. The soil organic matter content was generally high ranging from $2.34-6.57 \%$, with the higher rate at Piku followed by Tum and Mirnga sites. The total Nitrogen $(\mathrm{N})$ varies among sites with a low ranging estimate of $0.04-0.83 \%$, which average was higher at Daura then Garwashina followed by Tum sites. The available Phosphorus $(\mathrm{P})$ varies between moderate and high (4.20 - $21.70 \mathrm{ppm})$ with significant difference $(\mathrm{p}<0.05)$ among sites. The basic cations $(\mathrm{K}, \mathrm{Ca}, \mathrm{Mg}$, and Na) differ $(\mathrm{p}<$ $0.05)$ in the study sites. The exchangeable $\mathrm{K}(0.64-2.94) \mathrm{Cmol}(+) / \mathrm{kg}$, was consistently low to very low, while Ca (3.80 $16.4 \mathrm{Cmol}(+) / \mathrm{kg})$ and $\mathrm{Na}(0.60-2.80 \mathrm{Cmol}(+) / \mathrm{kg})$ saturation. In all the sites Piku compared higher in organic matter, followed by Tum sites in the study sites. The stability of soil aggregate increase with increase in organic matter content, the high macroporosity and permeability of these aggregate decreases run off and soil erosion rates [11]. Kigir site with comparable moderate estimate of O.M, N, P, Na, Mg, and TEB, which are widely reported as soil erosion mitigators in most environment, this concurs with the report of $[32,33]$ that organic matter, nitrogen, Phosphorus, Magnesium and Calcium are soil erosion mitigators. 


\begin{tabular}{|c|c|c|c|c|c|c|}
\hline Chemical Property & Kigir & Piku & Daura & Mirnga & Garwash & Tum \\
\hline Soil $\mathrm{p} \mathrm{H}\left(1: 2: 5\right.$, soil $\left.\mathrm{H}_{2} \mathrm{O}\right)$ & 7.81 & 7.96 & 7.28 & 7.42 & 7.39 & 7.43 \\
EC $(\mathrm{dSM}-1)$ & 0.03 & 0.04 & 0.03 & 0.04 & 0.04 & 0.04 \\
Organic matter $(\%)$ & 2.34 & 6.57 & 2.91 & 3.48 & 3.07 & 6.22 \\
Total Nitrogen $(\%)$ & 0.04 & 0.07 & 0.83 & 0.10 & 0.24 & 0.22 \\
Exch. Phos. $(\mathrm{ppm})$ & 4.20 & 4.55 & 21.70 & 6.55 & 8.05 & 11 \\
Exch. K (cmol $(+) / \mathrm{kg})$ & 1.05 & 0.64 & 2.94 & 0.67 & 0.97 & 0.95 \\
Exch. $\mathrm{Ca}(\mathrm{cmol}(+) / \mathrm{kg})$ & 16.4 & 6.20 & 5.60 & 6.00 & 9.80 & 3.80 \\
Exch. Mg(cmol $(+) / \mathrm{kg})$ & 2.20 & 1.60 & 1.00 & 0.60 & 2.80 & 1.60 \\
Exch. $\mathrm{Na}(\mathrm{cmol}(+) / \mathrm{kg})$ & 1.13 & 1.74 & 0.78 & 0.57 & 0.39 & 0.65 \\
TEB $(\mathrm{cmol}(+) / \mathrm{kg})$ & 20.78 & 10.18 & 10.32 & 7.84 & 13.96 & 7.00 \\
$\mathrm{SE}+/-0.05$ & 2.31 & 1.35 & 1.04 & 2.05 & 1.53 & 1.24 \\
\hline
\end{tabular}

Table 2: Chemical Properties of Soil of the Study Sites

\subsection{Soil Erosion Predictor Variables at Different Sites}

Table 3, shows the 14 selected soil erosion predictor variables. The selected soil erosion predictor variables were significantly ( $\mathrm{p}<0.05)$ different among study sites in terms of soil clay content, site slope rating, rainfall and runoff factor, plastic limit, soil calcium, infiltration rates and temperature of the study area. This soil difference was perhaps due to varying soil texture that regulated both soil erodibility and plastic behaviours [25]. The action of climate and inherent soil properties which influences the site runoff and slope variability might be the factors that caused the differences. Higher plastic limit was recorded at Daura, Piku and Kigir compared to Garwashina, Mirnga and Tum sites could have been responsible for the soil loss differences observed at these sites. This observation concurs with the report of [25] that soil texture and structure influence the degree of soil plasticity and erodibility given additional moisture input that precludes erosion losses. Similar observation was made by [34] that land use practice and lower clay accumulation predisposed soil to both increased erodibility and soil loss indices. Also, the wide variation in terms of soil bulk density, clay content, soil infiltration rates, temperature of the study area, cover and management factor, support practice factor, soil shear strength and organic matter content across sites could be limited to similar parent material and organic matter that formed the soil in addition to comparable vegetation and land use practice, this observation agreed with that of $[35,36,37]$ that parent material source are largely responsible for soil behaviours.

The influence of the fourteen (14) erosion predictor variables exhibited both mitigatory and facilitatory behaviours on soil loss pattern in the study sites. The soil cover and management factor, temperature of the study area, soil bulk density, infiltration rate, organic matter content, support practice factor, soil shear strength, soil calcium and clay content, mitigated soil loss, while the runoff, plastic limit, site slope, soil erodibility and soil sodium facilitate soil loss in the study area. These were significantly difference $(\mathrm{p}<0.05)$ among site, this observation concurs with those of $[11,28,34,35$, 36, 37], that soil texture, soil structure (e.g. macroporosity), aggregate properties, organic matter and chemical content, hydraulic properties, erodibility and parent material influence soil loss.

\begin{tabular}{|c|c|c|c|c|c|c|c|c|c|c|c|c|c|c|}
\hline $\begin{array}{c}\text { Study } \\
\text { Site(\%) }\end{array}$ & $\begin{array}{l}\text { Clay } \\
\text { Con. }\end{array}$ & $\begin{array}{c}\text { Erod. } \\
\text { BD } \\
\left(\mathrm{g} / \mathrm{cm}^{3}\right)\end{array}$ & $\begin{array}{l}\text { Soil } \\
\text { OM } \\
(\%)\end{array}$ & $\begin{array}{c}\text { Soil } \\
\text { ST } \\
\text { (KPa) }\end{array}$ & $\begin{array}{c}\text { Soil } \\
\text { SR(\%) }\end{array}$ & $\begin{array}{c}\text { Site } \\
\text { Run } \\
\text { off } \\
(\mathrm{mm})\end{array}$ & $\begin{array}{l}\text { Rainfall } \\
\text { MF (\%) }\end{array}$ & $\begin{array}{c}\text { Cover } \\
\text { Practice } \\
\text { Factor }\end{array}$ & $\begin{array}{c}\text { Support } \\
\text { SA } \\
\left({ }^{\circ} \mathrm{C}\right)\end{array}$ & $\begin{array}{c}\text { Temp } \\
\text { (Cmol } \\
(+) / \mathbf{k g})\end{array}$ & $\begin{array}{c}\text { Soil } \\
\text { Na }\end{array}$ & $\begin{array}{c}\text { Plastic } \\
\text { LM } \\
(\%)\end{array}$ & $\begin{array}{l}\text { Soil Ca } \\
(\mathrm{Cmol} \\
(+) / \mathrm{kg}\end{array}$ & $\begin{array}{c}\text { SoilInfiltration } \\
\text { Rate } \\
\left(\mathrm{mmh}^{-1}\right)\end{array}$ \\
\hline Kigir & 32.00 & 0.25 & 1.25 & 2.34 & 0.02 & 25 & 327.00 & 0.40 & 0.2 & 27 & 1.13 & 18.34 & 16.40 & 7.97 \\
\hline Piku & 19.50 & 0.35 & 1.38 & 6.57 & 0.03 & 20 & 346.52 & 0.05 & 1.0 & 32 & 1.74 & 18.53 & 6.20 & 14.85 \\
\hline Daura & 19.50 & 0.42 & 1.38 & 2.91 & 0.01 & 25 & 396.87 & 0.40 & 1.0 & 30 & 0.75 & 19.23 & 5.60 & 1.66 \\
\hline Mirn. & 24.50 & 0.25 & 1.38 & 3.48 & 0.01 & 20 & 299.80 & 0.50 & 0.5 & 25 & 0.50 & 5.78 & 6.00 & 12.56 \\
\hline Gar. & 24.50 & 0.25 & 1.38 & 3.07 & 0.01 & 20 & 310.82 & 0.05 & 0.5 & 34 & 0.39 & 7.0 & 9.80 & 6.52 \\
\hline Tum & 17.00 & 0.34 & 1.33 & 6.22 & 0.08 & 25 & 289.12 & 0.40 & 1.0 & 28 & 0.65 & 6.82 & 3.80 & 12.17 \\
\hline $\mathrm{SE}$ & 2.21 & 0.03 & 0.02 & 0.03 & 0.01 & 1.12 & 16.01 & 0.08 & 0.14 & 1.36 & 0.20 & 2.76 & 1.87 & 1.98 \\
\hline
\end{tabular}

Table 3: Soil Erosion Predictor Variables at Different Sites

Key: Clay Cont. $=$ Clay Content, Erod. $=$ Erodibility, Soil BD = Soil Bulk Density, Soil Organic Matter, Soil ST = Soil Shear Strength, Rainfall Runoff = Rainfall and Runoff Factor, Cover MF = Cover and Management Factor, Temp. SA =Temperature of the Study Area, Plastic LM = Plastic Limit

\subsection{Monthly Measurement of Soil Loss in the Study Sites}

Table 4, shows the result of monthly measurement of mass of soil loss (MSL) estimates which was $10.210-99.750$ $\mathrm{kgha}^{-1} \mathrm{yr}^{-1}$, respectively in 2016. It generally expressed significantly $(\mathrm{p}<0.05)$ higher erosion rates at Kigir, Piku and Daura sites between June and August, when rainfall amounts were higher in the study area. Similar influence of rainfall on erosion activities were reported by [40, 38, 39]. 


\begin{tabular}{|c|c|c|c|c|c|c|}
\hline Study site & Kigir & Piku & Daura & Mirnga & Garwashina & Tum \\
\hline \multicolumn{7}{|c|}{ Mass of Soil Loss $\left(\mathrm{kgha}^{-1} \mathrm{yr}^{-1}\right)$} \\
\hline April & $15.22^{\mathrm{Y}}$ & $1.44^{\mathrm{I}} 8.67^{\mathrm{c}}$ & $135.71^{\mathrm{c}}$ & $5.30^{\mathrm{f}}$ & $3.93^{\mathrm{h}}$ & $1.85^{\mathrm{I}}$ \\
May & $45.38^{\mathrm{N}}$ & $20.99^{\mathrm{u}}$ & $145.82^{\mathrm{B}}$ & $9.87^{\mathrm{b}}$ & $30.55^{\mathrm{Q}}$ & $8.37^{\mathrm{d}}$ \\
June & $132.57^{\mathrm{b}}$ & $110.86^{\mathrm{F}}$ & $81.22^{\mathrm{I}}$ & $20.5^{\mathrm{v}}$ & $49.82^{\mathrm{m}}$ & $25.17^{\mathrm{T}}$ \\
July & $150.28^{\mathrm{A}}$ & $30.67^{\mathrm{a}}$ & $99.75^{\mathrm{G}}$ & $118.82^{\mathrm{c}}$ & $75.22^{\mathrm{I}}$ & $75.23^{\mathrm{I}}$ \\
Aug. & $88.11^{\mathrm{N}}$ & $15.87^{\mathrm{x}}$ & $33.97^{\mathrm{a}}$ & $66.18^{\mathrm{k}}$ & $20.11^{\mathrm{w}}$ & $20.11^{\mathrm{w}}$ \\
Sept. & $33.37_{\mathrm{p}}$ & $10.95^{\mathrm{z}}$ & $50.27^{\mathrm{L}}$ & $26.83^{\mathrm{Y}}$ & $15.23^{\mathrm{Y}}$ & $7.81^{\mathrm{e}}$ \\
Oct. & $15.87^{\mathrm{x}}$ & & $29.25^{\mathrm{R}}$ & $4.99 \mathrm{~g}$ & $10.21^{\mathrm{a}}$ & $5.30^{\mathrm{Y}}$ \\
SE $_{+-0.05}$ & $6.85^{* *}$ & & & & \\
\hline
\end{tabular}

Table 4: Mean Value of Empirically Estimated Mass of Soil Loss in the Study Sites

Source: (Based on Field Data, 2016)

4.5. Means of Annual Mass of Soil Loss (MSL) Estimated Using Empirically Estimated and RUSLE 2, Predicted Models in the Study Sites

The empirically estimated and RUSLE 2, predicted mass of soil loss are presented in Table 5. Empirically estimated model showed Geometric mean error ratio (GMER) closed to one (1) and smaller Geometric standard deviation of error ratio (GSDER). Model with a GMER closed to 1 and smaller GSDER used to be the best model in terms of prediction strength [43]. Empirically estimated model had higher prediction strength than RUSLE 2, predicted model. The higher prediction strength of the empirically estimated model was because; it has no depth of soil restriction in terms of application. While RUSLE 2, predicted has restricted depth of application and it was designed in the United States of America [31, 41].

\begin{tabular}{|c|c|c|}
\hline Study & Empirically Estimated Model & RUSLE 2, Predicted Model \\
\hline Sites & $\left(\mathrm{kgha}^{-1} \mathrm{yr}^{-1}\right)$ & $\left(\mathrm{kgha}^{-1} \mathrm{yr}^{-1}\right)$ \\
\hline Kigir & 26.74 & 207.14 \\
Piku & 25.47 & 248.96 \\
Daura & 26.91 & 248.68 \\
Mirnga & 39.59 & 243.02 \\
Garwashina & 36.68 & 351.85 \\
Tum & 32.91 & 240.40 \\
GMER & 0.99 & 2.07 \\
GSDER & 5.91 & 49.17 \\
\hline
\end{tabular}

Table 5: Mean Annual Mass of Soil Loss (MSL) Estimated Using Empirically

Estimated and RUSLE 2, Predicted Models.

Key: GMER = Geometric Mean Error Ratio, GSDER = Geometric

Standard Deviation of Error Ratio

\section{Conclusion}

The extent of soil erosion was quantified using empirically estimated and RUSLE 2, predicted techniques under same condition of Biu environment. The pattern, rate and estimate of MSL confined to rainfall amount as the seasoned progressed to peak in the month of July and therefore declined with the cessation of rainfall in October the study area. The empirically estimated model was developed for the prediction of soil loss from multiple regression analysis between 14 selected erosion predictor variables. Soil erosion was significantly $(\mathrm{p}<0.05)$ higher at Kigir, Tum, Daura, and Garwashina while it was low at Piku location in this study.

\section{Acknowledgement}

The authors would like to express to Nigeria's Tertiary Education Trust Fund (TETFund), through College of Education Waka - Biu, School of Vocational Education for funding the research, and much needed time and support for the field experiments. Further acknowledgement goes to the University of Maiduguri, Faculty of Agriculture and Soil Science Department for physio - chemical analysis in the laboratory.

\section{Reference}

i. G. Wang, G. Gartner, S. Fang and A. B. Anderson (2003) Mapping multiples variables for predicting soil loss by Geostatistical methods with TMImages and slope map. Photogrammetric Engineering and Remote Sensing vol. 69: No. 8 pp. $889 \quad-898$.

ii. W. H. Wischmier and D. D. Smith (1958) Rainfall energy and its relationship to soil los Transaction of American Geological Union 39: 285 - 91

iii. D. C. Flanagan, and M. A. Nearing (1995) USDA, Erosion prediction project Hill slope profile and watershed model Documentation MSERI, Report No. 10, USDA - ars, National soil erosion Research Laboratory West Lafayette Indiana.

iv. M. A. Nearing, H. Wei, J.J. Stone, F. B. Pearson, K. E. Spaeth, M. A. Welts, D. C. Flanagan and M. Hernandez (2011) a range land hydrology and erosion mode, Trans ASABE 54, 1 - 9 . 
v. K. G. Renard, C. R. Foster, G. A. Weesies, D. K. McCool and D. C. Yodder (1997) predicting soil erosion by water: A Guide to conservation planning with the Revised Universal Soil Loss Equation (RUSLE). USDA Agricultural Handbook No. 703, Government printing office, Washington DC., P. 404

vi. K. G. Renard and V. A. Ferreira (1993) RUSLE Model description and data base sensitivity. Journal of Environmental Quality 22(3): 458 - 466.

vii. L. M. Risse, M. A. Nearing, A. D. Nicks and J. M. Laflen (1993) Error Assessment in the Universal Soil Loss Equation Soil Science Society of America Journal, 57 (3): $825 \quad-833$.

viii. L. Benkobi, M. J. Trilica and J. L. Smith (1994) Evaluation of a refined surface cover sub factor for use in RUSLE Journal of Range Management, 47(1): 74 - 78.

ix. J. Biesemans, M. V. Meivenae, and Gabriel (2000) Extending the RUSLE with Monte Carlo error propagation technique to predict long time average off - site sediment accumulation. Journal of Soil and Water Conservation, First Quarter: 35 - 42.

x. R. P. C. Morgan (2005). Soil Erosion and Conservation (3rd edition) Blackwell Science Limited, a Blackwell publishing Company, 350 Main street, maiden MA 02148 - 5020, USA P. 45 - 48.

xi. H. Blanco and Ratan L. (2008) principles of soil conservation and Management, Springer Science Business media the Ohio State University, Columbia, Ohio USA Kansas State University Hys. Ks USA

xii. P. S. Amaza (2007). Baseline Socio - economic Survey Report, Agriculture, Borno State, Nigeria. International Institute of Tropical Agriculture (IITA) Ibadan, Nigeria pp. 7

xiii. G. Rottenburry, J. R. Rickson, and R. Ross (1988) Gully erosion in Bedfordshire Freak Weather on farming practice? Paper presented at the $4^{\text {th }}$ Benelux Catholic University of Leaven.

xiv. E. I. Ekwue, and Y.Y. Tashingwa (1993) Survey of Gully Erosion features in Mubi Local Government Area, Adamawa State. Journal of Annals of Borno Vol. 8/ 9, University of Maiduguri Press.

xv. Ministry of Agriculture and Natural Resources Biu (Biu - MANR), Biu, Borno State.

xvi. B. Usman (2015). A History of Biu, Biu Emirate Studies Series (BESS 003) PublishedbyKlamidas Communication Limited Sinti BO 4 Peak Plaza, Jabi Expressway, Utako Distric, Abuja, Nigeria Pp. 27 - 28.

xvii. M. J. Shipitalo and W. M. Edwards (1998) Runoff and erosion control with conservation tillage and reduced input practices on cropped Watershed, Soil Tillage Res. 46: 1 - 12.

xviii. C. Y. Evert and R. S. Kenwar (1992) Interpreting Tension Infiltration Data for quantifying soil macrospores; some practical consideration Traans ASABE 36: 423 - 428.

xix. J. S. K. Mitchell and G. D. Budnezer (1993) Fundamentals of soil behaviour (2nd eds) John Wiley New York.

xx. E. J. Roose (1975) Erosion et. ruissellementre Afrique de louses vigt annees de measures en pentiles par celles experimendles Cyclo ORSTOM. A diopodouine: Ivory Coast.

xxi. R. P. C. Morgan (1974) Estimating regional variation in soil erosion hazard in Peninsular Malaysia; Malay: Nat. J. $28:$ $94-106$.

xxii. G. R. Foster, L. J. Lane, J. D. Newton, J. M. Laflen and R. A. Young (1981) Estimating erosion and sediment yield on field sized areas Trans. Am. Soc. Agric, $\quad$ Engrs: 24: 1253 - 63

xxiii. T. T. Trout, I. G. Garcia - Castilas and W. E. Hart (1987). Soil water engineering, field and laboratory manual M/S Eurasia, New Delhi, India

xxiv. B. Wolf (2003). Diagnosis techniques for improving crop production. Haworth Press, USA.

xxv. K. H. Head (1992) Manual of soil laboratory testing vol. 1 soil classification and compaction test Partech press, London P, 119 - 158.

xxvi. A. Walkley and C. Black (1934) chronic acid titration method for determining soil organic matter: soil science society of America, Journal 37: 29.

xxvii. W. H. Wischmier and D. D. Smith (1978) Predicting rainfall losses, USDA - Agric. Res. Service. Handbook, 539

xxviii. B. Wolf (2003) Diagnostic technique for improving crop production. Haworth press USA.

xxix. R. H. Bray and L. T. Kurtz (1945) Determination of total organic carbon and available forms of phosphorus in the soils: Soil Science Society of America. Journal 59: 39 - 45.

xxx. M. L. Jackson (1965). Soil chemical analysis practice Hall, New York, USA.

xxxi. USDA - ARS (2008) User reference Guide, RUSLE 2, Washington DC, USA.

xxxii. J. Poessen and G. Govers (1990) Gully erosion in the Loam belt of Belgium typology and control measure in Boardman J. Foster, I. D. I and Nearing, J. A. (EVS) Pp. 513 - 530.

xxxiii. I. B. I. Tarasenko (1981) Increasing fertility of the soils of Cuba, Book Publisher, Krasnodar, USSR, Pp. 189.

xxxiv. G. R. Foster (1986) Understanding ephemeral Gully Erosion, soil conservation, Assessing the National Research Inventory, National Research Council Board on Agriculture 2. National Academy Press Washington DC Pp. 90 - 118.

xxxv. [M. E. Obi and B. Asiegbu (1980) the physical properties of some eroded soils south eastern Nigeria. Journal of Soil Science, 130: 392 - 400.

xxxvi. S. O. Ojeniyi and G. O. Iremiren (1990) Impacts of cropping practice on erosion control in Ondo State. A paper presented on the $4^{\text {th }}$ Benelux Colloquium in April, University of Amsterdam and Catholic University of Leven.

xxxvii. R. P. C. Morgan (1995) Soil erosion and Conservation $2^{\text {nd }}$ edition Longman Scientific and technical published in the United States with John Wiley and sons Inc. New York, USA. Pp. 3-12.

xxxviii. R. I. Wasson, I. J. Olive and C. J. Roswell (1996) Rallies of erosion and sediment transport on Australis in: Walling D. \& Webk B (ds) Erosion and sediment Yields Global and Regional perspectives. I. A. Publications 239: 130 - 184. M. 
C. Massiyandima (2000) The hydrology of small agricultural Watersheds in Guinea Savannah Zone of West Africa. Ph.D Thesis, Cornell University Ithaca.

xxxix. K. Vandale (1993). Assessment of Factors Affecting Ephemeral Gully Erosion in

Cultivated Catchment of the Belgian Loess Belt, farmland in temperate plains: Environment and Hills. Elsevier, Pp. 125 - 136.

xl. USDA - NRCS (2008). Soil Conservation Service and Reference Service, USDA - Burca of land Management, and US Army Corps engineers

xli. E.J. Murray, R. H. Jones and D.W. Rix (1997) Relative Importance of Factors Influencing the Permeability of Clay soils: Geoenvironmental Engineering Thomas Tedford London.

xlii. K.M. Wolter (1985) Introduction to Variance Estimation, New York, Springer - Verlag 